\title{
Influence of Digital Technologies in Trade on Economic Development ${ }^{2}$
}

The digital trade agenda has been increasing the past few decades. However, it became so large that the system of international trade cannot match the pace of the development of digital innovations and technologies. This article focuses on discussing disruptive technologies with the correlation to the socioeconomic development, as well as understanding the gains of inclusive trade and using different economic trade policy instruments to ensure the balance between the implementation of tools and the digital economy. The major point of this article is to explain what measures have to be taken to narrow the gap between the countries with different development levels.

Key words: trade policy, economic instruments, e-commerce, country differentiation, multilateral agreements, transparency, socio-economic development.

\section{JEL: O35}

\section{Introduction}

The development of Internet commerce and the creation of the digital economy enables the countries to experience impressive possibilities to increase the economic production cycle which meet human needs and improve welfare of people. Consequently, this does not prevent the countries from an increase in new capacities, such as institutions, other regulatory methods and techniques and measures focused on ensuring proportional development. The inclusiveness of the process is ensured through compensating for problems and imbalances. With a successful example of the U.S agenda, which is considered to be very transparent and a very expanded one, U.S trade institutions have proposed several key facts:

- To give the whole information about their digital trade policies

- To promote open access to the internet

- To prohibit digital customs duties

- To secure discrimination

- To enable cross-border data flaws

- To prevent localization barriers, issues about the transfer of the technologies

1 Rourke Phil- Executive Director, Centre for Trade Policy and Law (CTPL), Carleton University/University of Ottawa, Canada. E-mail: <rznworld@gmail.com>. 
- To protect critical source codes

- To ensure technology choices

- To advance innovative authentication methods, network competition, consumer protection, encryption,

- To build adaptable frameworks

- To ensure cybersecurity, standardization

- To increase market access

- To make more transparent customer procedures.

These issues are very complex and difficult to deal with, that is why the WTO is facing these problems and is searching for a solution that would enable these issues to become simpler and more transparent. Such a solution has to take into account and review the procedure of how trade documentation is issued (see Fig. 1).

The trend over the digitalization and trade changes, the services make changes, while transportation and providing trade finance skills are services relative to education and other skills which are essential to produce mass scaled goods [2, pp. 59-61]. Crucially, the trade finance process is highly fragmented across numerous entities (see Fig. 2). These trends, furthermore, might decrease the cost of market entry if one can lower the cost of the goods down to a reasonable level that small firms can grow and find particular niches in the industries.

\section{General impact on economic development}

These trends and changes, overall, have a deep impact on the trade system. One of the impacts is that information technology is increasingly pervasive, accessible and affordable [3, p. 15-17]. Moreover, the different combinations of technologies could multiply this impact. While consumers enjoy great benefits, producers have to create new business models in this area in a whole host of others.

There is also an influence on employment and unemployment. The employment and unemployment effects, i.e. matching work with new jobs, is a type of structural problems that other countries face.

One more important fact is related to increased competition between those who have access versus those that do not or have less access to digital technology [4, p. 386]. Technology impact differs between and among developed and developing countries and within those groupings.

\section{Distribution of benefits}

The link between current mainstream and potential is not considered to be clear, thus it is very difficult to plan and to implement the rules that would apply and be reasonable and work to the advantage of the country if it starts negotiating as soon 


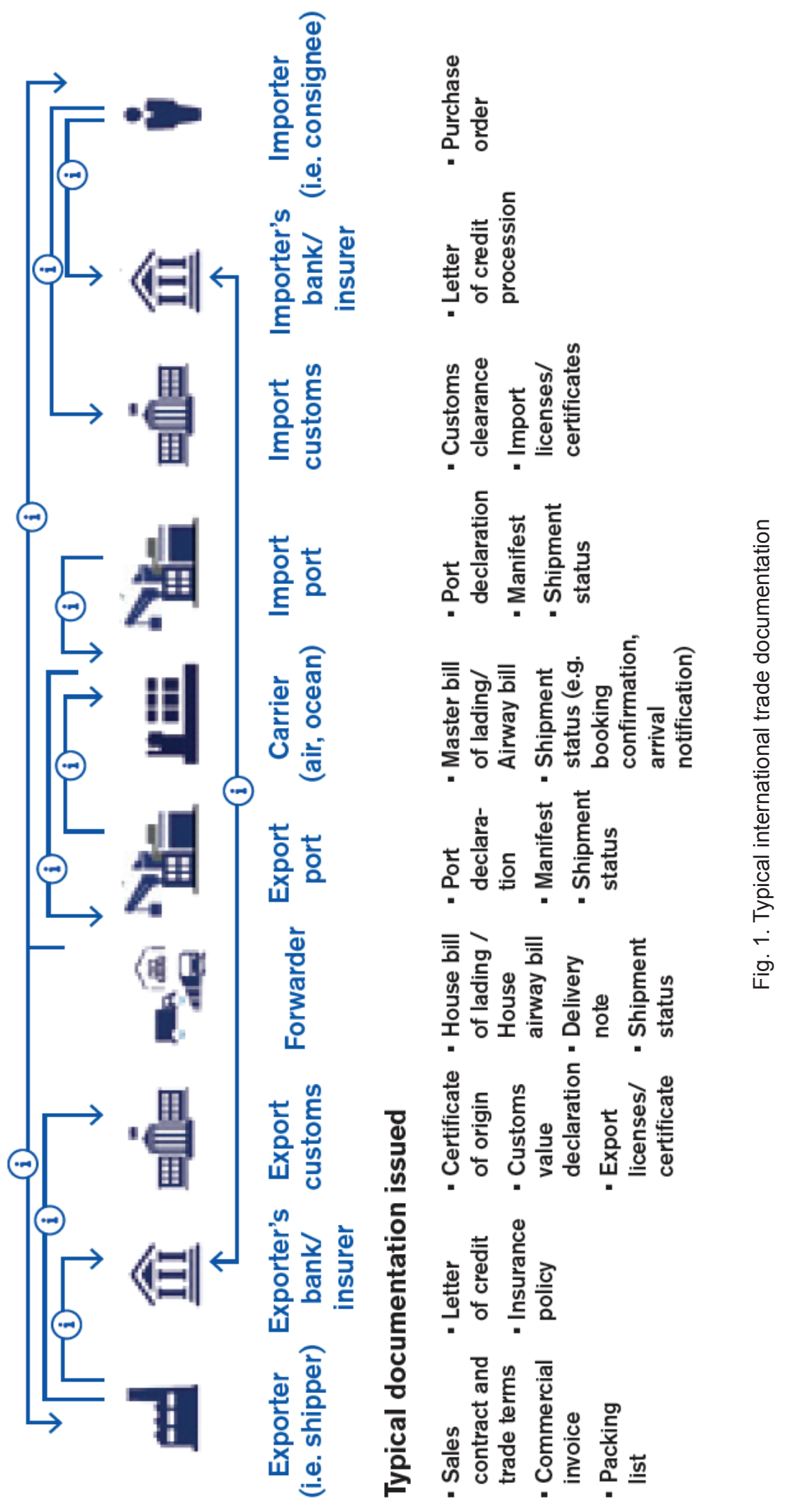




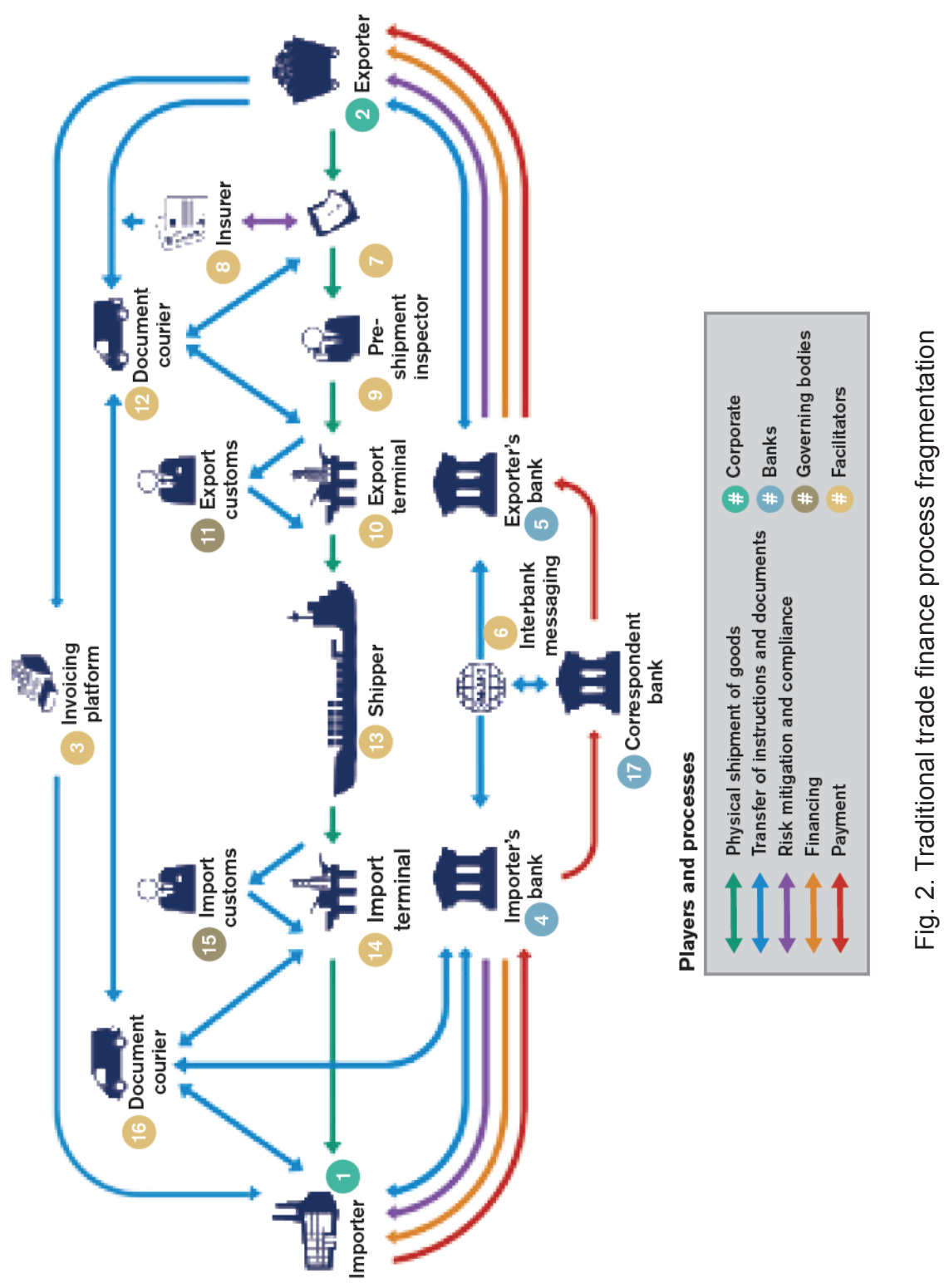


as possible. One more significant issue to mention about disruptive technologies that the biggest destructor, an innovation yet may have not even been created. That means that the disruptive technologies change at a very high pace, thus they have to be approached under a high surveillance [5, p. 25, 38].

The new problems met by the WTO on the topic of the development of disruptive economic technologies are:

- The difference between the socio-economic statuses among the countries

- The business environment and internal regulations appear to dictate the level of trade possibilities in order to get access to the market

- The problems of new infrastructure that provide high possibilities of copying.

By now, the response has been made at regional and bilateral levels, although yet there are sets of inclusive growth issues to be seen and approached.

The main question arises whether the WTO is capable of achieving the practical steps of in the next ten years and whether there is an efficient mechanism to address challenges of social economic development.

Trade negotiations are suggested as an effective tool to increase customer market access. However, it is not dedicated only to the market access, but to a whole combination of various factors. The trade rules, as suggested within the session of the WTO, take a great amount of time to be implemented and to be efficiently put to work.

Another exclusive tool to solve the current issues is cooperation agreements outside of the trade agreements. It is a different mechanism that can be used to address some of the issues, where the trade issues, which are to be negotiated, are so far intractable.

Second technique that could be valuable to the resolution is the implementation deficit of facilitation agreements. This affects customs procedures and borders as costs of doing business. However, there is a whole combination of other implementation issues that can address social economic development issues.

The final methodology is the most important one - the domestic reform.

\section{Conclusion}

The existing multilateral rules for regulating trade relationships are aimed at the possibility of building a balanced trade system. With the ability to create an equal and fair environment for the trading sides which assumes the need to take into consideration the factors of different starting levels, economic and organizational capabilities, and the need for development assistance. All these propositions manifest themselves in the trade system alongside mechanisms of special and differential treatment and the possibility of applying unilateral trade preferences. 


\section{References}

[1] World Trade Organization (2018) Can Blockchain revolutionize international trade? URL: <https://www.wto.org/english/res_e/booksp_e/blockchainrev18_e.pdf>.

[2] Negroponte N. (1995) Being Digital, New York: Alfred A. Knopf. Publishing House.

[3] Sundararajan A. (2016) The Sharing Economy: The End of Employment and the Rise of CrowdBased Capitalism. Cambridge, MA: MIT Press.

[4] Jorgenson, D. W., Vu, K. M. (2016) The ICT revolution, world economic growth, and policy issues. Telecommunications Policy, 40. P. 383-397.

[5] Zuboff S. (2015) Big other: Surveillance capitalism and the prospects of an information civilization. Journal of Information Technology, 30(1): 75-89. 
Рурк Ф. ${ }^{1}$

\section{Влияние циффровых технологий в торговле}

\section{на экономическое развитие}

Повестка цифровой торговли наполняется на протяжении нескольких последних десятилетий. Однако она стала настолько обширной, что изменение системы международной торговли отстает от темпов развития цифровых инноваций и технологий. В статье уделено внимание подрывным технологиям и их взаимосвязи с социально-экономическим развитием, а также выгодам от инклюзивной торговли и применения торгово-политического инструментария в целях обеспечения баланса между применяемыми мерами и цифровой экономикой. В статье рассмотрены меры, которые необходимо применять для сокращения разрыва в экономическом развитии между странами.

Ключевые слова: торговая политика, экономические инструменты, электронная торговля, дифференциация стран, многосторонние соглашения, транспарентность, социально-экономическое развитие.

JEL: $\mathbf{O 3 5}$

1 Рурк Фил - Исполнительный директор, Центр торговой политики и права, Университет Oттавы, Канада. E-mail: <rznworld@gmail.com>.

2 Статья поступила в редакиию в ноябре 2018 г. 